\title{
Feasibility Study of the Development of Grand Forest Park in Gunung Wayang, Bandung Regency, West Java, Indonesia
}

\author{
$R$. Qurrataayun ${ }^{1}$, Parikesit $^{1,2,3}$ and $S$. Withaningsih ${ }^{1,2,3}$ \\ ${ }^{1}$ Evironment Science Program, Postgraduate School, Universitas Padjadjaran, Bandung, West Java, Indonesia \\ ${ }^{2}$ Centre for Environment dan Sustainability Science, Universitas Padjadjaran, Bandung, West Java, Indonesia \\ ${ }^{3}$ Department of Biology, Faculty of Mathematic and Natural Sciences, Universitas Padjadjaran, Sumedang, West Java, Indonesia
}

\begin{abstract}
Gunung Wayang area is located inthe upstream part of the Citarum river basin. Forest preservation in the upper Citarum watershed is very important to maintain its sustainability. However, along with the increasing population and increasing demand for land, Gunung Wayang forest area faces increasing threats and disturbances from various deforestation activities, such as encroachment, illegal logging, and forest land conversion, which then worsening the condition of the Citarum watershed. One of the initiatives of the Government of Bandung Regency is the development of Grand Forest Park at Gunung Wayang. Therefore, this research aimed to identify, study, and analyze the feasibility of developing Grand Forest Park in this location. The method used was mixed-methods with a parallel convergent mixed approach. The results of the study indicate that there were several types of plants and animals with important conservation status. Grand Forest Park will increase many new economic opportunities and decrease deforestation activities. However, because nearly $70 \%$ of the people living around the area are farmers cultivating land in forest areas, therefore a comprehensive approach is needed to avoid conflicts related to land ownership.
\end{abstract}

\section{Introduction}

Degradation of forests and land in watersheds in Indonesia is relatively worrying, so that the carrying capacity of watersheds is less than optimal in supporting community welfare. During the rainy season, there are floods and landslides, while in the dry season there is drought. This condition reflects a decrease in the carrying capacity of watersheds that occur in almost all parts of Indonesia [1]. Based on the Decree of the Minister of Forestry of the Republic of Indonesia Number: SK.328 / Menhut-II / 2009, there are around 108 priority watersheds that are spread across almost all parts of Indonesia, and the Citarum watershed is one of the priority watersheds in West Java Province and is also included in the 15 National Priority Watershed [2].

The Citarum River has an important role for the surrounding community, including as a source of irrigation water for approximately 420,000 hectares in West Java Province, and as a place for the existence of 3 (three) large dams that function as a power plant of 1,900 MW for Java and Bali region [3]. The Gunung Wayang area, located in Kertasari District, Bandung Regency, is the upstream part of the Citarum watershed and has been designated as a protected forest since 2003. Indeed, the upstream part of the watershed should be designated as a protection function, because the upstream ecosystem is an important part of the protection function of all parts of the watershed [4].
However, along with the increasing population and increasing demand for land, forest preservation in the Gunung Wayang area has experienced various threats and disturbances from various land use activities in the form of encroachment, illegal logging, and forest land conversion which continues to increase.

The upstream condition of the Citarum watershed has suffered quite worrying damage. Hectarage critical Citarum upstream region has reached 80,000 hectares [5], and surface run-off flows that occur at 3632.50 million $\mathrm{m}^{3} / \mathrm{year}$, sedimentation of 7898.59 tons/ha and erosion has reached 491 tons $/ \mathrm{Ha} /$ year with very poor erosion index class [15]. This situation will certainly worsen the condition of the Citarum watershed, can exacerbate the effects of flooding, shorten the life of the existing dams, the land around the upstream is slowly damaged, the springs experience silting, and the water catchment area becomes drastically reduced so that it affects public welfare.

The response from the government in an effort to improve the Citarum watershed is the issuance of Government Regulation Number 15 of 2018 concerning the acceleration of pollution control and damage to the Citarum River Basin, and the Bandung Regency Government as the manager of the upstream part of the Citarum watershed has the initiative to plan the development of a Grand Forest Park in the Mount Wayang area. As a solution to overcome problems that 
occur in the Mount Wayang area and also as part of efforts to restore the Citarum watershed.

However, from any change in the function of the area, there will be impacts, both on the environment, social, economic, and cultural conditions of the community as well as institutional consequences and laws and regulations. Therefore, a feasibility study is needed in the development plan of the Grand Forest Park in the Gunung Wayang area based on the biophysical environmental aspects, social, economic, and cultural aspects of the community as well as institutional and statutory regulations. Due to the success of tourism development in an area, it is necessary to have a balance between the environmental, economic, and sociocultural aspects of the community so that sustainable tourism can occur [6]. So it is hoped that the development plan for the Grand Forest Park in the Gunung Wayang area can meet the sustainability aspects and support the control of damage and pollution to the Citarum watershed.

The purpose of this research is to identify, study, and analyze the feasibility of developing a Grand Forest Park in the area of Mount Wayang. In doing so, this research focuses on the biophysical, social, economic, and cultural aspects of the community as well as the supporting institutions and regulations.

\section{Material and Methods}

\subsection{Study site}

This research was conducted in the area of Gunung Wayang, Kertasari District, Bandung Regency, West Java Province. The objects in this study include Gunung Wayang Area as a candidate for the development location of Grand Forest Park, the community living in and around the area, as well as stakeholders involved in the Grand Forest Park development plan. The research map is shown in Figure 1.

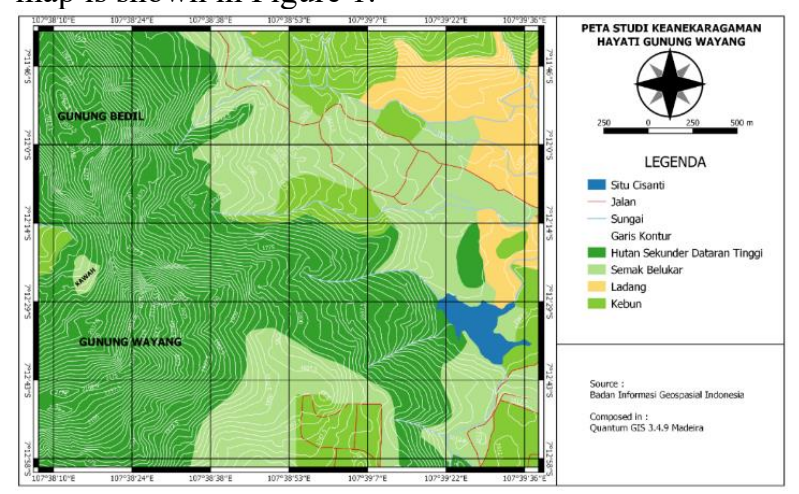

Fig. 1. Map of research studies in the Gunung Wayang area, Kertasari District-Bandung Regency, West Java Province, Indonesia.

\subsection{Research methods}

The method used was mixed methods with a parallel convergent mixed approach, namely a research approach that involves collecting quantitative and qualitative data. This method was chosen because a feasibility study for the development of a Grand Forest Park requires extensive and in-depth but specific data and information, not only data available from the location and object studied, but also other important data, both primary and secondary data. Qualitative methods are used to collect data on the biophysical conditions, social, economic, and cultural conditions of the community and their supporting institutions and regulations. Meanwhile, quantitative methods are used to analyze community participation and perceptions of the development plan for the Grand Forest Park in the Gunung Wayang area.

\subsection{Types and sources of data}

The feasibility study for the development of the Grand Forest Park in the Gunung Wayang area requires 2 (two) types of data, namely primary and secondary data. Primary data collection is obtained directly in the field using observation techniques, interviews, and questionnaires. Meanwhile, secondary data is collected through literature studies from various books, reports, research sources or publications, regulations, and other reliable sources.

Basically, the criteria that can support the sustainable management of a forest area include several general criteria, including biophysical, socio-economic, and cultural criteria for the community, as well as supporting institutions and laws and regulations. Grand Forest Park is built to collect natural or artificial plants and or animals, native and non-native species, which are used for research, science, education, cultivation support, culture, tourism, and recreation, with the main function of as a function of protection of life support systems, preservation of biodiversity and sustainable use of living natural resources and their ecosystems [7]. Based on this definition, the aspects or criteria contained in the Gunung Wayang area as a prospective Grand Forest Park development location need to be analyzed whether it is in accordance with the proper functions and objectives of the Grand Forest Park.

Data collection techniques used in this study include observation techniques, in-depth interviews, questionnaires, and literature studies. The criteria, indicators, variables, types of data, and data collection methods used in the feasibility study for the development of the Grand Forest Park in the Gunung Wayang area are shown in Table 1.

In the community involvement indicator, the data source in the quantitative approach is the respondent. Respondents as samples are determined using simple random sampling which belongs to probability sampling, namely a sampling technique that provides equal opportunities for each population to be selected as sample members. Determination of the number of samples was determined using the Slovin formula, with a $90 \%$ confidence level and an acceptable error limit of 0.1 , the number of samples taken is 98 samples for each village. 
Table 1. Criteria, Indicators, Variables, Types of data, and data collection methods

\begin{tabular}{|c|c|c|c|c|c|}
\hline No & Criteria & Indicator: & Variables & $\begin{array}{c}\text { Types of } \\
\text { data }\end{array}$ & Collection techniques \\
\hline 1. & $\begin{array}{l}\text { Bicphysical } \\
\text { Eavironanent }\end{array}$ & $\begin{array}{l}\text { Water resources } \\
\text { Flon } \\
\text { Fauna } \\
\text { Soil } \\
\text { Topography } \\
\text { Rainfall } \\
\text { Natural Tourism } \\
\text { Attraction } \\
\text { Objocts }\end{array}$ & 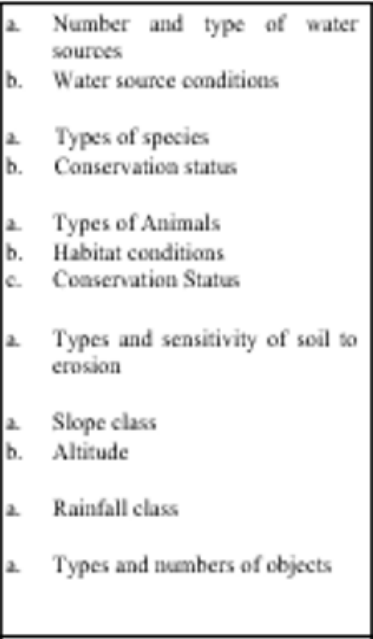 & $\begin{array}{l}\text { Primary and } \\
\text { Secondary } \\
\text { Secondary } \\
\text { Secondary } \\
\text { Secondary } \\
\text { Secondary } \\
\text { Secondary } \\
\text { Primary axd } \\
\text { Secondary }\end{array}$ & $\begin{array}{c}\text { Observation, } \\
\text { Inserview, Literature } \\
\text { Study } \\
\text { Literature review } \\
\text { Literature review } \\
\text { Literature review } \\
\text { Literature review } \\
\text { Literature review } \\
\text { Observation, } \\
\text { Inserview, Literature } \\
\text { Study }\end{array}$ \\
\hline 2 & Legal & $\begin{array}{l}\text { Regulations } \\
\text { Spatial plans }\end{array}$ & $\begin{array}{l}\text { 2. Various suppocting laws and } \\
\text { policies (Ceatral, Provincial, and } \\
\text { District) } \\
\text { 3. Study of regional spatial } \\
\text { planniag; } \\
\text { b. Study of sechnical regulations } \\
\text { for the developuseat of Grand } \\
\text { Forest Park } \\
\text { a. Institutional form plans in the } \\
\text { management of Grand Forest } \\
\text { Park }\end{array}$ & $\begin{array}{l}\text { Primary and } \\
\text { Secondary } \\
\text { Primary and } \\
\text { Secondary }\end{array}$ & $\begin{array}{l}\text { Interview, Literature } \\
\text { Study } \\
\text { Interview, Literature } \\
\text { Study }\end{array}$ \\
\hline 3. & $\begin{array}{l}\text { Social, } \\
\text { Ecoocmic, and } \\
\text { Cultural }\end{array}$ & $\begin{array}{l}\text { Populatioes } \\
\text { Mobility } \\
\text { Local culture } \\
\text { and wisdom } \\
\text { Cousmuaity } \\
\text { involvement } \\
\text { Ecooomy }\end{array}$ & 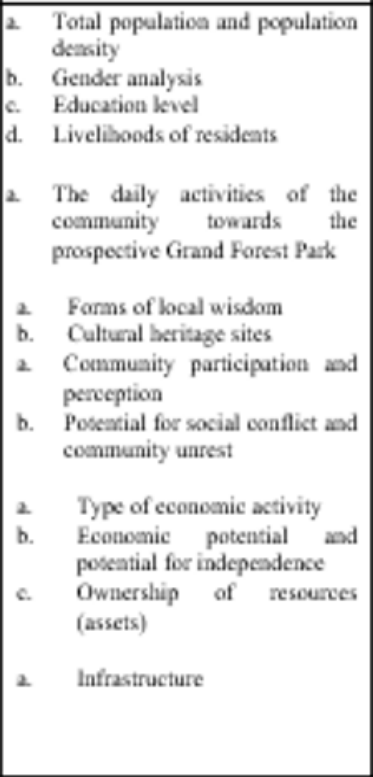 & $\begin{array}{l}\text { Primary } \\
\text { Primary and } \\
\text { Secondary } \\
\text { Primary } \\
\text { Primary } \\
\text { Primary and } \\
\text { Secondary }\end{array}$ & $\begin{array}{c}\text { Interview, Literature } \\
\text { Study } \\
\text { Observation, } \\
\text { Inserview, Literature } \\
\text { Study } \\
\text { Interview, } \\
\text { Questicenaire } \\
\\
\text { Observation, Inservien }\end{array}$ \\
\hline
\end{tabular}

In-depth interviews were conducted with competent parties with sufficient knowledge regarding the development plan for the Grand Forest Park in the Gunung Wayang area. The sample selection in qualitative research is done intentionally or purposive sampling.

\section{Results}

\subsection{The general condition of the study location}

Gunung Wayang area is located in Kertasari DistrictBandung Regency, West Java Province, which is the upstream part of the Citarum watershed. Mount Wayang is a twin volcano with Mount Windu and is included in the category B type of volcano or volcano that is in the furmarola/solfatara activity level, and since 1600 it has never experienced a magma eruption [8]. Gunung Wayang area is categorized into sub-montane mountain forest with the soil type that dominates the Gunung Wayang area is the Podsolic type and the altitude above sea level varies from 1,000-2,400 meters. In 2018, the rainfall was $1,500 \mathrm{~mm} /$ year with an average of 4.12 $\mathrm{mm} / \mathrm{month}$. The air is very cool climate ranging between $13^{0}-23^{0}$ Celsius[9]. In the Wayang Mountain area, around 60 springs are found scattered around 
Cibeureum Village and Tarumajaya Village, Kertasari District-Bandung Regency.

In the Gunung Wayang area, there is an area managed by Perum Perhutani KPH Bandung Selatan, and the feasibility study for the development of the Grand Forest Park is focused on 4 (four) compartments, namely plots $68,69,73$, and 18 . The following is a map of the compartments in the development plan. The Grand Forest Park in the Mount Wayang area is shown in Figure 2.

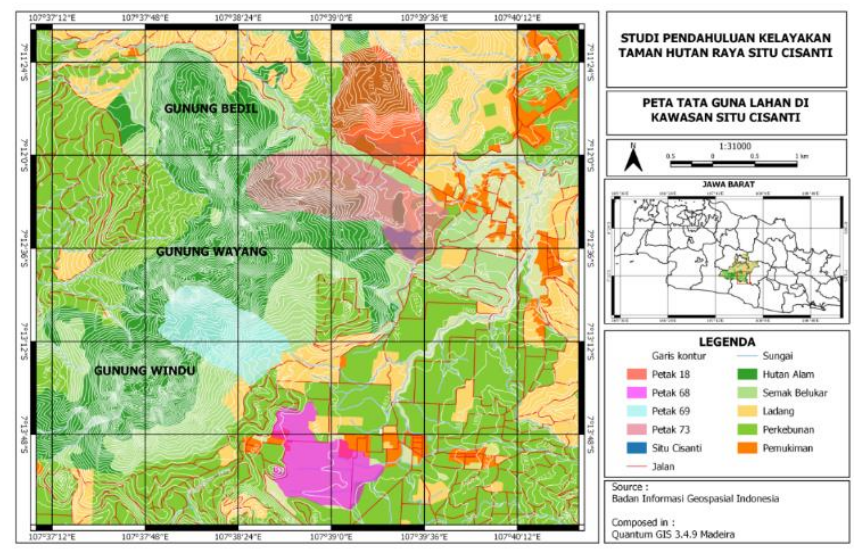

Fig. 2. Map of plot locations in the plan to develop a Grand Forest Park in the Gunung Wayang area

\subsection{Vegetation conditions}

The forest in the Gunung Wayang area is categorized into sub-montane mountain forests with vegetation types that are often found, including Rasamala (Altingia excelsa), Jamuju (Dacrycarpus imbricatus), and Ki Putri. (Podocarpus Neriifolius), Ki Hujan (Engelhardia spicata), Saninten (Castanopsis argenta), and Puspa Kembang (Schima walichii).

There were about 26 plant species found in the Wayang Mountain area, and grouped according to their conservation status based on the Regulation of the Minister of Environment and Forestry P. 106 of 2018, the International Union for Conservation of Nature (IUCN Redlist), and the Convention on International Trade in Endangered Species of Wild Fauna and Flora (CITES). The following is a list of plant species found in the Mount Wayang area, shown in Table 2.

Table 2. Plant types obtained in the Gunung Wayang area-Bandung Regency, West Java Province, Indonesia

\begin{tabular}{|c|c|c|c|}
\hline \multirow{2}{*}{ PP } & \multicolumn{2}{|c|}{ IUCN } & \multirow{2}{*}{ CITES } \\
\hline & LC & EN & \\
\hline $\begin{array}{l}\text { Saninten (Castanopsis. } \\
\text { argantea) }\end{array}$ & 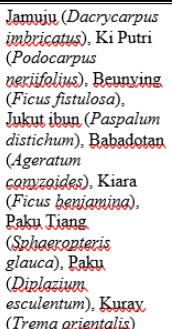 & $\begin{array}{l}\text { Ki Hujan } \\
\text { (Exgelhardia spicata) }\end{array}$ & $\begin{array}{l}\text { Ki Putri (Podocarpus } \\
\text { neriifflius), Paku } \\
\text { Jiang (Sphgercpteris } \\
\text { glauca) }\end{array}$ \\
\hline
\end{tabular}

\subsection{Avifauna/Bird diversity}

Found about 36 species of birds from 25 families found around the Gunung Wayang area. Data from the inventory of bird species in the Gunung Wayang area are shown in Table 3.

Table 3. Bird type in the Gunung Wayang area, Kertasari District-Bandung Regency, West Java Province, Indonesia

\begin{tabular}{|c|c|c|c|c|c|c|}
\hline \multirow[b]{2}{*}{ No. } & \multirow[b]{2}{*}{ Local Names } & \multirow[b]{2}{*}{ Scientific } & \multirow[b]{2}{*}{ Family } & \multicolumn{3}{|c|}{ Conservation Status } \\
\hline & & & & Pp & IUCN & CITES \\
\hline 1. & Elays Hitam & Letrogetus malaikutis & Accipitridae & $\sqrt{2}$ & LC & Aped I \\
\hline 2. & Cipoly lacat & Segichinativelia & Aesithinidar & & LC & \\
\hline 3. & Celakak Jawa & 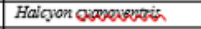 & \multirow{3}{*}{ Alcedinidge } & & LC & \\
\hline 4. & Celakgak expgai & 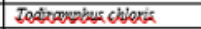 & & & LC & \\
\hline 5. & $\begin{array}{l}\text { Raja adays } \\
\text { menuxting }\end{array}$ & 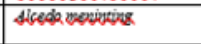 & & & LC & \\
\hline 6. & Kapinis nomph & 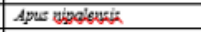 & \multirow[b]{2}{*}{ Apodidae } & & LC & \\
\hline 7. & WValet linghi, & Collocalia lijoshi & & & LC & \\
\hline 8. & Cinenen belabp & 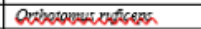 & Cisticolidge & & LC & \\
\hline 9. & Telolbur biasa & Spitapelig chinentis & \multirow{2}{*}{ Columbidae } & & LC & \\
\hline 10. & Localbuan & 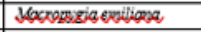 & & & LC & \\
\hline 11. & STrovk belaben & 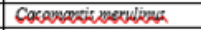 & Cyculistere & & LC & \\
\hline 12. & Sriguntivg belakph & 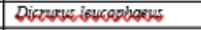 & Dispuidise & & LC & \\
\hline 13. & Bondoljawa & 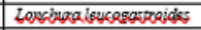 & \multirow{2}{*}{ Expildidae } & & LC & \\
\hline 14. & Bondolpeking & Lenshagagousculata & & & LC & \\
\hline 15. & Alapoalapaspi & Falco wolucewate & Eakopidae & 8 & LC & $\operatorname{seg} \sqrt{\pi}$ \\
\hline 16. & Lavass dayang & 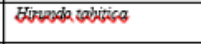 & Hirumdinidae & & LC & \\
\hline 17. & Benter kelaten & Lavius skback & \multirow[b]{2}{*}{ Lavidase } & & LC & \\
\hline 18. & Bentet boseng & Laviun tistions & & & LC & \\
\hline 19. & Sigatan ninon & Everevigs inckigo & \multirow{3}{*}{ Muscicapidae } & & LC & \\
\hline 20. & Cinccospge bing & Brackestenx mentaga & & & LC & \\
\hline 21. & Bycicabutan, & 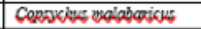 & & & LC & \\
\hline 22. & $\begin{array}{l}\text { Buruse wadp } \\
\text { ariganti. }\end{array}$ & Crvarisisugularis & Nectranipidae & & LC & \\
\hline 23. & 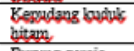 & Qviabus chinensis & Oriolidae & & LC & \\
\hline 24. & $\begin{array}{l}\text { Eurwogereja } \\
\text { ersaia }\end{array}$ & Passer movoputh & Rasseridge, & & LC & \\
\hline 25. & $\begin{array}{l}\text { Puwab gopsong } \\
\text { Jaus }\end{array}$ & 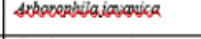 & Phasianidae & & LC & \\
\hline 26. & Caladitilike & 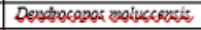 & Picidae & & LC & \\
\hline 27. & Berancetberdil & Exossiga pusilita & Ryeqpizidar & & LC & \\
\hline 28. & Cucak batilang. & 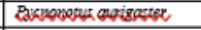 & \multirow{2}{*}{ Pycnonotidae } & & LC & \\
\hline 29. & Skgobat culkcolk & Rasugeverus geigujex & & & LC & \\
\hline 30. & Beluk ketura & 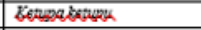 & \multirow{3}{*}{ Strigidae } & & LC & \\
\hline 31. & Celegovikroban & Oas sompix & & & LC & Aypd I \\
\hline 32. & SerakJawa & Tyzo aiba & & & LC & \\
\hline 33. & Keralk berion & Acridethoreriavavicus & Stumidae & & vU & \\
\hline 34. & Anis werala & Geekichja citrine & Turdidae & & LC & \\
\hline 35. & Jingjigg batu & 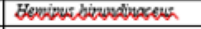 & Jangisag & & LC & \\
\hline 36. & Escapata biass & 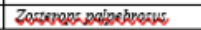 & Zosteropidar & & LC & \\
\hline
\end{tabular}

\subsection{Mammals}

There are 5 (five) types of mammals from three families found in the Gunung Wayang area. These include Macaca fascicularis, Apodemus flavicollis, Callosciurus notatus, Ratufa bicolor, and Sus sp. The following list of mammal species found in the Mount Wayang area is shown in Table 4.

Table 4. Data on mammal species found in the Wayang Mountain area, Kertasari District-Bandung Regency, West Java Province, Indonesia.

\begin{tabular}{|c|c|c|c|c|c|c|}
\hline \multirow[b]{2}{*}{ No. } & \multirow[b]{2}{*}{ Local Names } & \multirow[b]{2}{*}{ Scientific } & \multirow[b]{2}{*}{ Family } & \multicolumn{3}{|c|}{ Conservation Status } \\
\hline & & & & PP & IUCN & CITES \\
\hline 1. & $\begin{array}{l}\text { Aonyet ekor } \\
\text { paniang }\end{array}$ & Macaca fascicularisa & Cercopithecidae & & $\overline{\mathrm{LC}}$ & App II \\
\hline 2. & Tikus kebun & Arederwus flaxicallis & Muridae & & LC & \\
\hline 3. & Baing kelapa & Callosciwnus notanus & S.i. & & LC & \\
\hline 4. & Jelarang hitam & Ratufabicolor & Sciuridae & & NT & AppII \\
\hline 5. & Babi & Sus sp. & Suidae & & LC & \\
\hline
\end{tabular}

\subsection{Social dan Economic conditions}

location of the Grand Forest Park development plan in the Wayang Mountain area is adjacent to 2 (two) villages, namely Cibeureum Village and Tarumajaya Village, Kertasari District, Bandung Regency. The following is the population data in Cibeureum Village and Tarumajaya Village, shown in Table 5. 
Table 5. Population data of Cibeureum Village and Tarumajaya Village, Kertasari District-Bandung Regency, West Java Province, Indonesia.

\begin{tabular}{|c|c|c|c|c|c|}
\hline \multirow{2}{*}{ No. } & \multirow{2}{*}{ Village } & \multirow{2}{*}{$\begin{array}{c}\text { Total population } \\
\text { (person) }\end{array}$} & \multirow{2}{*}{$\begin{array}{c}\text { Population } \\
\text { density }\end{array}$} & \multicolumn{2}{|c|}{ Gender } \\
\cline { 5 - 6 } & & & & Merson $/ \mathrm{km}^{2}$ ) & Women \\
\hline \hline 1. & Cibeureum & 22.625 & 869 & 11.735 & 10.890 \\
\hline 2. & Tarumaiaxa & 15.527 & 566 & 7.566 & 7.961 \\
\hline
\end{tabular}

Source: BPS Kertasari District in number 2018

The main source of income for most of the residents of Cibeureum and Tarumajaya Villages is as farmers and farm laborers. The age composition of the population in Cibeureum and Tarumajaya Villages is dominated by productive age, namely between 26 years and 55 years, and the education level of the population that dominates both villages is the Primary School level.

\section{Discussion}

\subsection{Analysis of the biophysical aspects}

The Grand Forest Park is a nature conservation area built to collect endemic or non-endemic plants and animals and is used for research, education, culture, and tourism activities. The existence of plant and animal species that are endemic and have conservation status is an important asset for the development of a Grand Forest Park.

The Gunung Wayang Forest area is dominated by vegetation types that make up sub-montane mountain forests, tree species that are easy to find include Rasamala (Altingia excelsa), Jamuju (Dacrycarpus imbricatus), and Ki Putri (Podocarpus Neriifolius). Species that have protected status based on Ministry of Environment Regulation No.106 of 2018 are Saninten (Castanopsis argenta). According to the IUCN, there are 9 (nine) types that have Least Concern (LC) status, including Babandotan (Ageratum conyzoides), Kiara (Ficus benjamina), Paku(PiangSphaeropteris glauca), Paku (Diplazium esculentum), and Kuray (Trema orientalis) and one type that has EN status, namely $\mathrm{Ki}$ Hujan (Engelhardia spicata). According to CITES, there is one type including appendix II and one type including appendix III, namely Paku(Piangsphaeropteris glauca) and $\mathrm{Ki}$ Putri (Podocarpus neriifolius).

It is known that several bird species fall into the protected category, namely from the families Accipitridae and Falconidae (Ictinaetus malaiensis and Falco moluccensis). According to the IUCN, most birds in the Wayang Mountain area have the status of Least Concern, only Acridotheres javanicus is Vulnerable. Meanwhile, based on CITES, there are three types of birds that are recorded as Appendices II, namely Ictinaetus malaiensis, Falco moluccensis, and Otus lempiji.

There were 5 (five) types of mammals found in the Gunung Wayang area, and based on the PP.106, no mammals were recorded as protected on Mount Wayang and Windu. According to the IUCN, one type is included in status, Near Threatrned namely Ratufa bicolor, and three types are included in the Least Concern, namely, Macaca fascicularis, Apodemus flavicollis, and Callosciurus notatus. According to CITES, two types of mammals are included in the category Appendices II, namely, Macaca fascicularis and Ratufa bicolor.

Several types of plants were also found which are characteristic of the mountainous flora of West Java Province, such as Jamuju (Dacrycarpus imbricatus) and Ki Putri (Podocarpus Neriifolius), while endemic fauna types include Javanese Gonggong Quail (Arborophila javanica), Serak Jawa (Tyto alba), and Cekakak Jawa (Halcyon cyanoventris). The existence of several species of plants and animals that are endemic and have important conservation status is an important asset in the development of a Grand Forest Park.

\subsection{Analysis of the socio-economic advantages and disadvantages}

The development of Grand Forest Park has a considerable impact on the communities around the area, especially on the economic aspect. If the development of the Grand Forest Park in the Mount Wayang area has been carried out, of course, there will be many economic opportunities for the surrounding community. Ecotourism development has a positive effect on the expansion of business and employment opportunities that arise due to demand from tourists[14]. Business opportunities such as lodging (hotels, homestays), restaurants, souvenir shops, tourist transportation services, tour guides, participating with the government in managing the Grand Forest Park, becoming a parking guard, and so on. This business opportunity will certainly provide opportunities for people around the area to work so that they can increase income to support the lives of local communities so that they can divert the community's habit of cutting wood and cultivating land in the Gunung Wayang forest area.

Currently, there are several economic activities in the community besides farming, such as selling handicrafts, cow milk, snacks, and coffee from farmers in the Gunung Wayang area. Economic activities like this will certainly be more developed if the Mount Wayang area is increasingly crowded with tourists.

However, the development of Grand Forest Park will also lead to conflict with the surrounding community. Conflicts that may arise include, among others, land ownership, because the majority of people around the area work as farmers and farm laborers on cultivated land in the forest area of Gunung Wayang. The government must offer other types of work to the community, especially for farmers whose land has to be closed. Therefore, socialization and information disclosure are needed to minimize social conflict.

\subsection{Social and economic analysis of society}

By using the Slovin formula, the respondents selected as samples in this study were 196 samples with an additional 4 samples so the total sample used was 200 samples (Table 6). 
Table 6. The number of residents in the study location and the number of samples

\begin{tabular}{|l|c|c|c|}
\hline \multicolumn{1}{|c|}{ Villages } & $\begin{array}{c}\text { Number of } \\
\text { household } \\
\text { heads }\end{array}$ & Sample & $\begin{array}{c}\text { Additional } \\
\text { Sample }\end{array}$ \\
\hline \hline Cibeureum & 5.318 & 98 & 2 \\
\hline Tarumaiaya & 4.765 & 98 & 2 \\
\hline \multicolumn{2}{|c|}{ Total } & 196 & 4 \\
\cline { 3 - 4 } & \multicolumn{2}{c|}{200} \\
\hline
\end{tabular}

The Gunung Wayang area is surrounded by 8 (eight) villages, and the prospective Grand forest park development location is adjacent to Cibeureum and Tarumajaya villages. Based on the results of the analysis of 200 samples, it is known that in their daily activities all respondents always enter the area and do activities in the Gunung Wayang area, because most of the villagers have jobs as farmers and farm laborers in the Gunung Wayang forest area.

\subsection{Community Participation}

The level of community participation in the development plan for the Grand Forest Park in the Gunung Wayang area will determine the success of the project implementation because, with the participation of local communities, the community feels more ownership in the project [12]. The level of community participation around the Gunung Wayang area in the development plan for the Grand Forest Park is still very small, only $14 \%$ for Tarumajaya and Cibeureum Villages at $18 \%$. In fact, based on the provisions of the Directorate General of Forest Protection and Nature Conservation, it states that in the management of forest areas, local communities must be actively involved to get job and business opportunities, and the sustainability of the social system can be achieved if community participation is high enough [13].

The low level of community participation in the development plan for the Grand Forest Park in the Gunung Wayang area is because the community's knowledge of the development plan, definition, function, and benefits of the Grand Forest Park is still limited. The communities around the Gunung Wayang area are dominated by farmers and farm laborers who cultivate land within the Gunung Wayang Forest area, therefore with the news about the Grand Forest Park development plan, the community is worried that they will not be able to to to farm to meet their needs. With this, the role of the government is urgently needed to disseminate information and provide clear information on the development plan for the Grand Forest Park to the communities around the area to create a conducive social climate and reduce conflicts that are likely to occur.

\subsection{Public Perceptions of the Grand Forest Park development plan community}

Perceptions and attitudes towards the existence and function of the forest in the Gunung Wayang area will influence the success of the conservation efforts that will be carried out. Natural resources cannot be conserved and managed properly without first knowing people's perceptions and attitudes towards the environment [10]. By knowing people's perceptions and attitudes towards natural resources, it will be easier to design effective conservation and management strategies to keep natural resources sustainable and meet the needs of the community[11]. Therefore, an assessment of perceptions and attitudes is very important to support the development plan for the Grand Forest Park in the Mount Wayang area. Following are the results of an analysis of community perceptions of the development plan for the Grand Forest Park and the existence of forests in the Mount Wayang area (Table 7).

Table 7. Public perception of the Grand Forest Park development plan and the existence of forests in the Mount Wayang area.

\begin{tabular}{|c|c|c|c|c|}
\hline No. & Perception & $\begin{array}{l}\text { Yes } \\
(\%)\end{array}$ & $\begin{array}{l}\text { No } \\
(\%)\end{array}$ & Total \\
\hline \multicolumn{5}{|c|}{ Cibeureum Village } \\
\hline 1. & $\begin{array}{l}\text { Knowing the status of the forest in the Gunung } \\
\text { Wlavang area as a protected forest }\end{array}$ & 55 & 45 & 100 \\
\hline 2. & $\begin{array}{l}\text { Knowing the role and benefits of the forest in the } \\
\text { Gusung, Wlayang area }\end{array}$ & 100 & 0 & 100 \\
\hline 3. & $\begin{array}{l}\text { Knowing the Grand Forest Park development } \\
\text { plan in the Gunung Wayang area }\end{array}$ & 7 & 93 & 100 \\
\hline 4. & $\begin{array}{l}\text { Knowing the meaning and benefits of the Grand } \\
\text { Forest Park }\end{array}$ & 8 & 92 & 100 \\
\hline 5. & $\begin{array}{l}\text { Agree and support the development of the Grand } \\
\text { Forest Park in the Gunung, Wayang }\end{array}$ & 17 & 83 & 100 \\
\hline 6. & $\begin{array}{l}\text { Development of the Grand Forest Park will affect } \\
\text { the preservation of forest on the Gunung. Wavang }\end{array}$ & 45 & 55 & 100 \\
\hline 7. & $\begin{array}{l}\text { Development of the Grand Forest Park will } \\
\text { provide economic benefits for the community }\end{array}$ & 17 & 83 & 100 \\
\hline 8. & $\begin{array}{l}\text { Development of the Grand Forest Park will cause } \\
\text { social conflict }\end{array}$ & 82 & 18 & 100 \\
\hline \multicolumn{5}{|c|}{ Jarumajaya Village } \\
\hline 1. & $\begin{array}{l}\text { Knowing the status of the forest in the Gunung } \\
\text { Wavang area as a protected forest }\end{array}$ & 14 & 86 & 100 \\
\hline 2. & $\begin{array}{l}\text { Knowing the role and benefits of the forest in the } \\
\text { Gunung Wavang area }\end{array}$ & 88 & 12 & 100 \\
\hline 3. & $\begin{array}{l}\text { Knowing the Grand Forest Park development } \\
\text { plan in the Gunung Wayang area }\end{array}$ & 0 & 100 & 100 \\
\hline 4. & $\begin{array}{l}\text { Knowing the meaning and benefits of the Grand } \\
\text { Forest Park }\end{array}$ & 0 & 100 & 100 \\
\hline 5. & $\begin{array}{l}\text { Agree and support the development of the Grand } \\
\text { Forest Park in the Gunung. Wayang. }\end{array}$ & 4 & 96 & 100 \\
\hline 6. & $\begin{array}{l}\text { Development of the Grand Forest Park will affect } \\
\text { the preservation of forest on the Gunung, Wavang }\end{array}$ & 79 & 21 & 100 \\
\hline 7. & $\begin{array}{l}\text { Development of the Grand Forest Park will } \\
\text { provide economic benefits for the community }\end{array}$ & 4 & 96 & 100 \\
\hline 8. & $\begin{array}{l}\text { Development of the Grand Forest Park will cause } \\
\text { social conflict }\end{array}$ & 80 & 20 & 100 \\
\hline
\end{tabular}

Based on the analysis of community perceptions of the development plan for the Grand Forest Park and the existence of the forest in the Gunung Wayang area, it is known that many people in Cibereum Village don't know the status of protected forest in the Gunung Wayang area, only $55 \%$ of the community knows. As for the role and benefits of the forest in the Mount Wayang area, most of the people already know about it, all respondents in Cibereum Village admit that the role and benefits of the forest in the Mount Wayang area are very significant for their survival. Regarding the development plan for the Grand Forest Park, the response from the community around the area still doesn't agree with the development plan. It can be seen that $83 \%$ of the people of Cibeureum Village and $93 \%$ of the people of Tarumajaya Village don't agree with the plan to develop the Grand Forest Park in the Gunung Wayang area. This result is possible because almost the entire community around the area doesn't yet know what the Grand Forest Park is, and the plans for the development of a Grand Forest Park in the Mount Wayang area. Almost all respondents (93\%) in Cibeureum Village and all respondents $(100 \%)$ in Tarumajaya Village didn't know about the Grand Forest Park development plan. Due to the ignorance of this information, the community is still worried about the loss of their livelihoods as farmers and agricultural laborers in cultivated land in the forest area of Gunung Wayang. With this, the community believes that social problems or conflicts will arise related to the community cultivated land in the Wayang Mountain area which will 
become a Grand Forest Park. Also, the community is still not sure of any economic opportunity after the existence of the Grand Forest Park.

Therefore, the role of the government is also urgently needed to conduct socialization and convey information about the development plan for the Grand Forest Park, how its benefits and effects are for the community, what economic benefits can be obtained, and how the community involvement system is in its implementation. With this, it is hoped that it can change the negative perceptions of the community about the development plan for the Grand Forest Park so that the development of the Grand Forest Park can be carried out and can reduce social conflicts.

\subsection{The Culture in the Gunung Wayang area}

The form of environmental conservation based on local knowledge in the communities around the area has now disappeared. In the past, people still had a fear of cutting down trees in the forests of Gunung Wayang, let alone cutting down, just injuring trees, they were feared by their beliefs at that time. However, currently, this trust has been lost, because they are pressed by economic needs. There are no indigenous groups around the Mount Wayang area, but there are several historical sites or relics that have become cultural assets in the Gunung Wayang area. Among other things, 7 (seven) water springs, the Kiara Jegang tree, and the "Petilasan Dipati Ukur" site in the Wayang Mountain area are precisely in plot 73 .

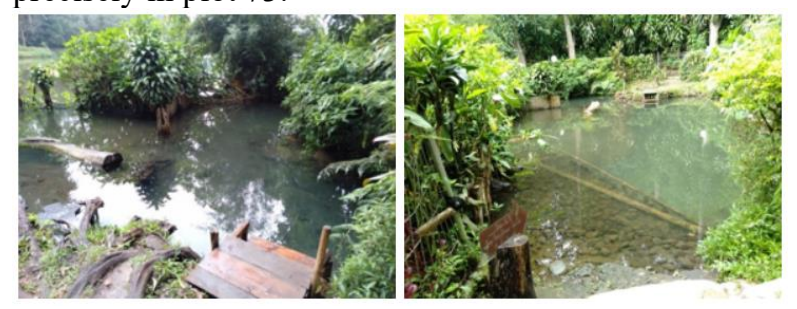

Fig. 3. Citarum and Cikahuripan Springs

There are 7 (seven) springs that irrigate Situ Cisanti, namely Citarum springs, Cikahuripan, Cikoleberes, Cihaniwung, Cisadane, Cikawuduk, and Cisanti. There are two springs, namely Citarum and Cikahuripan springs, whose history in ancient times this place was once the bathing place of Prabu Siliwangi and there is the footprint of his left foot. The people believe that these springs can clean physically and mentally, and many people from outside the area have to do "Napak Tilas" and prayer.

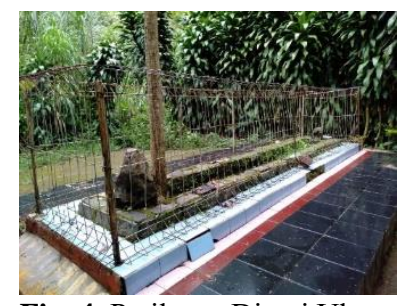

Fig. 4. Petilasan Dipati Ukur

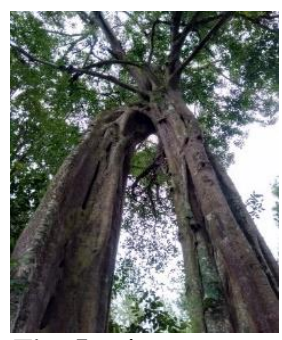

Fig. 5. Kiara Jegang
Besides that, there is "Petilasan Dipati Ukur" which is also a cultural asset of the local community. A leader once stopped by to perform "Napak Tilas", perform rituals of meditation and prayer in this area. It is characterized by a stone which indicates that Dipati Ukur had previously stopped at this place. With natural conditions that are still beautiful and calm, Dipati Ukur prefers to do meditation and pray in this area because the atmosphere is so calm. Also, there is a tree called "Kiara Jegang" which was sacred by the community because previously, this tree was used as a sign as a door to enter the Cisanti and Cikahuripan springs, which were once the bathing places of Prabu Siliwangi.

With the existence of these cultural assets, it must be protected and preserved because it is one of the historical heritages, and with this culture, people are more aware of protecting springs and preserving nature.

\subsection{Analysis of institutional aspects and statutory regulations}

Planning for the development of the Grand Forest Park in the Gunung Wayang area is supported by the following policies:

1. Bandung Regency Regional Regulation Number 27 of 2016 concerning the spatial plan for the Bandung Regency area for 2016-2036:

Article 6 states that the preservation of protected areas and the development of cultivation areas are based on the principle of sustainability;

Article 9 states that strategies to implement policies for the preservation of protected areas include: maintaining forest and non-forest protected areas, as well as other protected areas through efforts to rehabilitate and improve the quality of protected areas; developing cultivation activities with a protective function through the development of plants with conservation functions;

Article 10 states to organize and control areas that function as protection.

Currently, the protected forest in the Gunung Wayang area is managed by Perum Perhutani KPH Bandung Selatan but based on the Law of the Republic of Indonesia No. 23 of 2104 concerning regional government, article 14 (2) states that the management of the Grand Forest Park falls under the authority of the regional government. In connection with the development plan for the Grand Forest Park in the Gunung Wayang area, the institutional form of the management falls under the authority of the Bandung Regency Forestry Service.

\subsection{Facilities, Accessibility, and Potential Objects of Nature Tourism Attraction}

The facilities around the Gunung Wayang area are sufficient to support the development plan of the Grand Forest Park, such as the availability of health facilities, places of worship, restaurants, photo spots, souvenir shops, and public facilities such as toilets. However, lodging is still not available for visitors who want to stay overnight. To go to the Gunung Wayang area, it can be reached by land route with a distance of about $52 \mathrm{~km}$ from the city of Bandung. Access roads with concrete buildings have greatly helped smooth the journey to the destination. The potential for natural tourism dance objects in the Gunung Wayang area, namely Situ Cisanti 
which is $0 \mathrm{Km}$ from the Citarum watershed, there are 7 (seven) springs that can be directly witnessed by visitors, and the natural panorama around Situ Cisanti is still beautiful.

\section{Conclusions}

Geographically, the Gunung Wayang forest area has a strategic position for the development of a nature conservation area that has the function of protection, preservation of natural ecosystems, cultivation, and functions that support education, research, tourism, and development of local economic activities.

The existence of various endemic plant and animal species and have important conservation status in the Gunung Wayang forest area is an important asset for the development of the Grand Forest Park.

Culture and historical heritage sites in the Gunung Wayang area can support the development plan for the Grand Forest Park. Besides, the facilities, accessibility, and potential objects of natural tourist attraction in the Mount Wayang area are also adequate. Apart from farming, various economic activities of the community around the area can provide economic opportunities for the community.

The development of Grand Forest Park is faced with the challenges of social conflict that can arise. However, the development of the Grand Forest Park can also be an economic opportunity for the surrounding community. Therefore, the role of the government in socializing and providing information to the community is very necessary, so that the development plan for the Grand Forest Park can fulfill the sustainability aspects and can have an effect on improving the economy of the communities around the area.

\section{References}

1. Direktorat Jenderal Pengendalian DAS dan Hutan Lindung, Laporan Kinerja Direktorat Jenderal Pengendalian DAS dan Hutan Lindung (2019)

2. Kementrian Lingkungan Hidup dan Kehutanan, Rencana Strategis Tahun 2015-2019 Kementrian Lingkungan Hidup dan Kehutanan (2015)

3. Kurniawan, V., Ni Luh Shinta E. S., Widodo K., Annisa N. T., Arif S, Jurnal Bakti Masyarakat Indonesia 1 (2) 119-126 (2018)

4. Asdak, C., Hidrologi dan Pengelolaan Daerah Aliran Sungai, Gadjah Mada University Press, Yogyakarta (2010)

5. Mulyaningrum, Ellen R., Andre S., Prosiding PKM-CSR 2 (2019)

6. Milic, J. V., Jovanovic S., Krstic B., Facta Universitasis. Series: Economics and Organization 5 (2) 123-131 (2008)

7. Republik Indonesia, Undang-undang Nomor: 5 tahun 1990 tentang Konservasi Sumberdaya Alam dan Ekosistemnya (1990)

8. Bronto, S., Achnan K., Kaspar L., Jurnal Geologi Indonesia 1 (2) 89-101 (2006)
9. Badan Pusat Statistik Kabupaten Bandung, Kec. Kertasari dalam angka, BPS Kabupaten Bandung, Soreang (2019)

10. Lee, H. F. and Zhang, D. D., Environmental Management 41 (2) 168-182 (2008)

11. Dolisca, F., McDaniel, J. M. and Teeter, L. D., Forest Policy \& Economics 9 (6) 704-712 (2007)

12. Brandon, K., Langkah-langkah Dasar untuk Mendorong Partisipasi Lokal dalam Proyekproyek Wisata Alam, North Bennington: Ecotourism Society (1995)

13. Asdak, C., Kajian Lingkungan Hidup Strategis, Gadjah Mada University Press, Yogyakarta (2018)

14. Hidayati, D., Mujiyani L., Rachmawati, A. Zaelani., Ekowisata: Pembelajaran dan Kalimantan Timur, Pustaka Sinar Harapan, Jakarta (2003)

15. Imansyah, M. F., Jurnal Sosioteknologi 2511 